Dubravka Matoković

DOI: https://dx.doi.org/10.21857/yrvgqtelr9 Stručni članak

Rukopis prihvaćen za tisak: 21.12.2020.

\title{
MUZEOLOŠKA INTERPRETACIJA NAČINA ŽIVLJENJA U POŽEŠTINI KROZ MAKETU SEOSKE KUĆE IVE ČAKALIĆA
}

\begin{abstract}
Sažetak
Maketa tradicijske višeprostorne kuće iz Zbirke Ive Čakalića bila je sastavni dio nekoliko stalnih postava Gradskog muzeja Požega. Autor Ivo Čakalić, pučki umjetnik i seljak iz Doljanovaca, izradio ju je po uzoru na svoju rodnu kuću iz sredine 19. stoljeća. Opisani muzejski predmet predstavlja tipičan oblik tradicijske slavonske kuće. Na edukativan i svim uzrastima pristupačan način dokumentira izgled, funkciju i način stanovanja požeških seljaka od sredine 19. do početka 20. stoljeća. U višegodišnjoj komunikaciji s posjetiteljima pokazala se višeznačnost interpretacije samog predmeta. Na osnovi toga sam predmet postao je tematska ideja vodilja budućeg etnografskog dijela postava muzeja. Ideja je da se značajke tradicijske kulture sela Požeštine s kraja 19. i prve polovice 20. stoljeća prikažu u sklopu tradicijske kuće koja je bila prvi prostorni okvir seljačkoga života.
\end{abstract}

Ključne riječi: tradicijska kuća; predmet; tradicijska kultura; Ivo Čakalić; stalni postav.

\section{Uvod}

Etnološki odjel Gradskog muzeja Požega sustavno prikuplja bogatu građu tradicijske kulture požeškoga kraja. Radi se uglavnom o predmetima tekstilnog rukotvorstva i narodne nošnje, pokućstvu, predmetima koji su rabljeni u kućanstvu, gospodarstvu, obrtima i sličnome. Ta je građa unutar odjela raspoređena u dvanaest zbirki, a to su: Zbirka narodnih nošnji, Zbirka oglavlja i nakita, Zbirka tekstila, Zbirka vunenih prekrivača, Zbirka tradicijskog gospodarstva, Zbirka tradicijskog vinogradarstva i podrumarstva, Zbirka kućnog inventara i okućnice, Zbirka golobrdske lončarije i novoselskih pokljuka, Zbirka tradicijskog rukotvorstva i obrta te Zbirka Dragutina Lermana i Zbirka Ive Čakalića. Od spomenutih zbirki, Zbirka Dragutina Lermana čini iznimku jer se sastoji od korespondencije afričkog putnika i požeškog poduzetnika Dragutina Lermana, fotografija i raznih dokumenata vezanih uz njegov život i rad te malobrojnih predmeta iz Srednje Afrike. Zbirka Ive Čakalića čuva dio ostavštine seljaka etnografa i pučkog umjetnika Ive Čakalića. 


\section{Tko je bio Ivo Čakalić?}

Ivo Čakalić rodio se 1889. godine u selu Doljanovci sjeveroistočno od Požege, gdje je i umro 1971. godine. Seljak, etnograf, pučki umjetnik, pjesnik i redoviti hodočasnik u marijanska svetišta, "sveti Ivo“, kako su ga zbog njegove pobožnosti nazivali suseljani, još kao dječak volio je čitati knjige. Iako oskudnog školovanja, ${ }^{1}$ skupljao ih je i čitao cijeloga života, posebno one pisane ikavštinom. Ivo Čakalić govorio je, pisao i pjevao ikavicom, govorom svojega kraja. Od mladosti je sabirao i zapisivao narodne pjesme, a kasnije, u zrelijoj dobi, i tradicijske običaje svojega zavičaja. Bilježio je prošlost svojega sela, poslovice, priče, pjesme, molitve te godišnje i životne običaje. Neke je zapisao i po nekoliko puta. Životne teškoće koje su ga pratile od najranijeg djetinjstva prebrodio je strpljivošću, ustrajnom pobožnošću i predanim samoukim umjetničkim radom. Osim što je bio pučki pjesnik, uglavnom pišući nabožne pjesme, u svojim zrelim godinama izrađivao je dekorativne drvene predmete za sebe, rodbinu i prijatelje. ${ }^{2} \mathrm{U}$ svoje slobodno vrijeme drvenim nožićem oblikovao je drvene makete seoske arhitekture, poput zadružne kuće i mlina (slika 1). Često je radio po uzorku ili imitirajući pod utjecajem već viđenih predmeta religioznog karaktera, poput modela crkvi, skulptura svetaca i raspela, dodajući im nešto svoje jedinstveno po čemu je prepoznatljiv (Matoković, 2014). Njegove „umjetničke“ rukotvorine izazivale su divljenje njegove okoline, koja ih je dolazila razgledavati izložene u malom kućnom muzeju njegovih radova. Osim što je bilježio etnografsku građu potpapučkog dijela Požeštine, i sam je bio kazivač te suradnik muzikolozima i etnolozima onoga vremena ${ }^{3}$. Zahvaljujući njima, Čakalićeva rukopisna ostavština danas se čuva u nekoliko kulturnih i znanstvenih institucija. ${ }^{4}$

Ivo Čakalić završio je samo osnovno školovanje u susjednom selu Kaptolu.

2 Dio tih radova pohranjen je u Gradskom muzeju Požega, dok se ostali čuvaju u mjesnim kapelicama Požeštine i u privatnom vlasništvu.

3 Ivo Čakalić mnoge je tradicijske pjesme svojega kraja ispjevao muzikolozima Vinku Žganecu, Jerku Beziću i Josipu Andriću. Melografski zapisi tih pjesama čuvaju se u Institutu za etnologiju i folkloristiku i HAZU. Kao kazivač i suradnik na terenu surađivao je s etnologinjom Zdenkom Lechner, koja je 50-ih i dijelom 60-ih godina 20. stoljeća bila zaposlena u Muzeju Slavonije kao jedina etnologinja na cijelom području Slavonije, Baranje i Zapadnog Srijema.

4 Gradski muzej Požega, Muzej Slavonije u Osijeku te Institut za etnologiju i folkloristiku i Odsjek za etnologiju HAZU. 


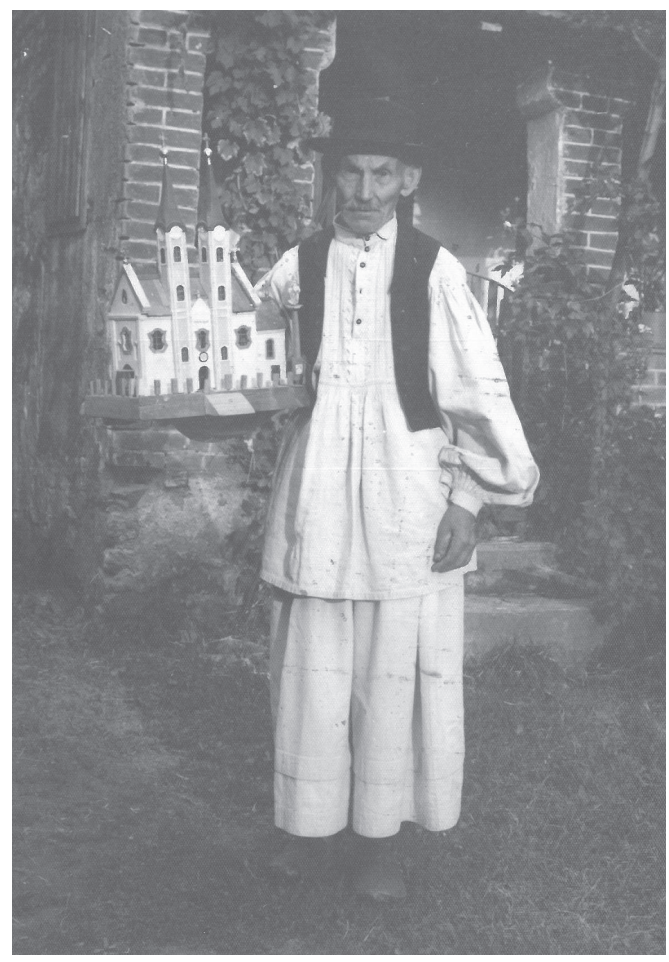

Slika 1. Ivo Čakalić s maketom crkve 60-ih g. 20. st., E 767, GMP

\section{Maketa seoske kuće Ive Čakalića}

Zbirka Ive Čakalića sadrži pretežno njegove rukopise u kojima su zabilježeni tradicijski običaji, poslovice i pjesme požeškoga kraja, pisma, prijepisi molitava i pjesama, obiteljske fotografije, makete seoske i sakralne arhitekture, slike i skulpture svetaca te raspela koja je Čakalić izrađivao od drva. Među njima se nalazi i model drvene višeprostorne kuće. Prema zapisima u inventarnoj knjizi ${ }^{5}$, maketa je otkupljena za muzej 1980. godine. U tadašnju Knjigu inventara Etnografske zbirke inventirana je pod brojem E 723 kao Maketa zadružne kuće. Prema rukopisnom zapisu samog autora, Ive Čakalića, maketa je izrađena po uzoru na njegovu rodnu, obiteljsku kuću sagrađenu 1862. godine u Doljanovcima. ${ }^{6}$ Izrađena je od drva veličine 78 x 39 x 58,5

\footnotetext{
Knjiga inventara Etnografske zbirke VII, Zbirka Ive Čakalića, Računalni inventarni program M++.

6 Zapis o izradi makete zadružne kuće, inv. br. E 679, darovan je Gradskom muzeju Požege, tada pod nazivom Muzej Požeške kotline, iste godine kada je maketa otkupljena za muzej. Prema tome rukopisu, zadružna kuća u kojoj se Ivo Čakalić rodio i živio do svoje četvrte godine bila je duguljasta zidanica sa skraćenim trijemom i poluskošenim krovom pokrivenim trstikom.
} 
$\mathrm{cm}$. Sastoji se od triju prostorija i trijema te je opremljena kućnim inventarom kakav je, prema Čakalićevu zapisu (Zbirka Ive Čakalića, inv. br. E 679), bio u drugoj polovici 19. stoljeća: veće sobe sa zidanom peći od petnjaka i klupom, stolom s klupama i stolicama, tkalačkim stanom te slikama na zidovima, zatim kuhinje s otvorenim ognjištem, suđem i priborom za kuhanje te zadnje prostorije - sobe s krevetom, klupama i stolom (slika 2).

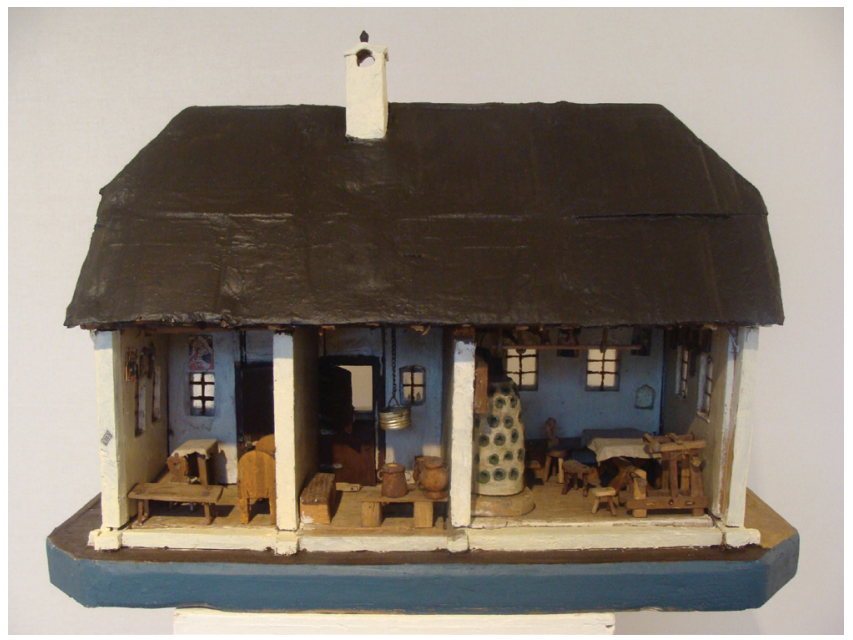

Slika 2. Maketa zadružne kuće 20. st., E 723, GMP

Sama maketa po svojem izgledu i rasporedu prostorija predstavlja tipični oblik tradicijske slavonske kuće. A to je troprostorna kuća pravokutnog tlocrta, zabatnog pročelja i linearnog rasporeda prostorija. Takva kuća sastoji se od: velike sobe sa zidanom peći za stanovanje svih ukućana, kuhinje s ognjištem u kojoj se pripremala hrana te sobe za kućnog starješinu ili za gosta (Španiček, 2009). Arhitektura stanovanja bila je prilagođena načinu življenja zadružne obitelji, nekoliko generacija rodbinski povezanih na istome mjestu.

Od svojega dolaska u muzej 1980. godine, Čakalićeva maketa višeprostorne zadružne kuće često je bila sastavni dio nekoliko stalnih postava i povremenih izložbi Gradskog muzeja Požega. Prezentirana je prvi put u sklopu etnografske cjeline Stalnog postava muzeja 1986. godine. U sklopu povremenih izložaba ${ }^{7}$ muzeja predstavljala je dio stvaralaštva svojeg autora ili je bila reprezentativan muzejski predmet Etnološkog odjela i njegove zbirke. Maketa je izlagana u privremenim postavima

\footnotetext{
Ivo Čakalić - seljak etnograf i umjetnik, 1991., Ljepota otkrića, 1999., Svjetlost muzejskih predmeta u Noći muzeja, 2008.
} 
Gradskog muzeja Požege 2003., 2006. i 2014. godine..$^{8}$ Etnografske cjeline u tim postavima bile su orijentirane na prikaze etnografskih značajki požeškoga kraja s naglaskom na tekstilno, lončarsko i drveno rukotvorstvo s elementima gospodarskog prikaza, seoske arhitekture, ali i samog stvaralaštva pučkog umjetnika Ive Čakalića (slika 3). U posljednja dva postava naglasak etnografske prezentacije bio je na

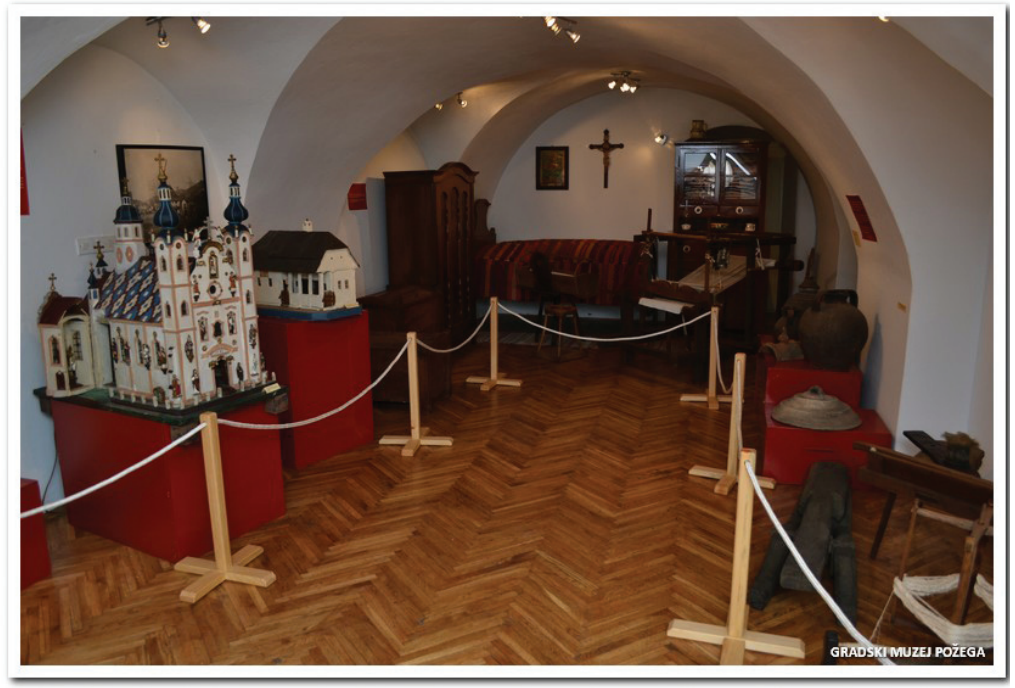

Slika 3. Privremeni postav iz 2006./2009. g., GMP

seoskoj arhitekturi i stanovanju. Zbog nedovoljno velikog izložbenog prostora za cjelovit prikaz tradicijskog ruralnog stanovanja, maketa zadružne kuće poslužila je kao dobar ilustrativni primjer tipične, stare seoske arhitekture požeškoga kraja. Na edukativan i svim uzrastima pristupačan način Čakalićeva maketa dokumentira tradicijsku kuću, način života, organizaciju prostora i oblik stanovanja požeških seljaka od sredine 19. do početka 20. stoljeća. Upravo ta njezina značajka iskorištena je u postavu iz 2014. godine pod nazivom Posljednji privremeni postav?? ${ }^{9}$ U suradnji

8 Gradski muzej Požega smješten je u kompleksu triju glavnih građevina iz različitih vremenskih perioda od 18. stoljeća do početka 20. stoljeća. U ljeto 1995. godine Požegu je pogodio jak potres i tada je narušena statika muzejskih zgrada, posebno glavne zgrade iz 18. stoljeća u kojoj je većim dijelom bio izložen stalni postav. Nakon obavljene potrebne sanacije i u čekanju konačne adaptacije muzejskih zgrada te u nedostatku stalnog postava, Muzej je tijekom idućih godina postavljao nekoliko varijanti privremenih postava u starim i novim izložbenim prostorima dobivenim (1996. i 2001. godine) za povremene izložbe. Uz to je imao i veliku izložbenu djelatnost od desetak izložbi godišnje (Šperanda, 2009; Žebčević Matić, 2011).

9 Obilježavajući 90. obljetnicu Gradskog muzeja Požega 2014. godine, otvoren je još jedan privremeni postav simboličnog naziva Posljednji privremeni postav? u nadi da je to zadnji prije konačne adaptacije muzejskog kompleksa. Ostavljajući prostor dotadašnjeg privremenog postava za druge izložbene pro- 
Etnološkog odjela s Odjelom povijesti umjetnosti prikazana je tematska cjelina svakodnevnog života i stanovanja u selu i gradu s prijelaza iz 19. u 20. stoljeće kroz lik žene i opremanje kuće. Zašto žena? Upravo je žena bila ona koja je vodila brigu o potrebama obitelji i vođenju kućanstva. Izloženi predmeti prikazali su razlike, ali i sličnosti gradskog i seoskog životnog prostora po načinu odijevanja žena, njihovu izgledu i ukrašavanju, kao i uređenju kuće i kućnog inventara u seoskoj i gradskoj kući $^{10}$ (slike 4 i 5). U ovoj tematskoj cjelini maketa zadružne kuće dobila je na važnosti jer prezentira seosku arhitekturu i stanovanje te se kao takva u interpretaciji mogla izdvojiti i u zasebnu priču. To se osobito moglo primijeniti u vođenju školskih grupa, koje su po više puta posjećivale muzej. ${ }^{11}$

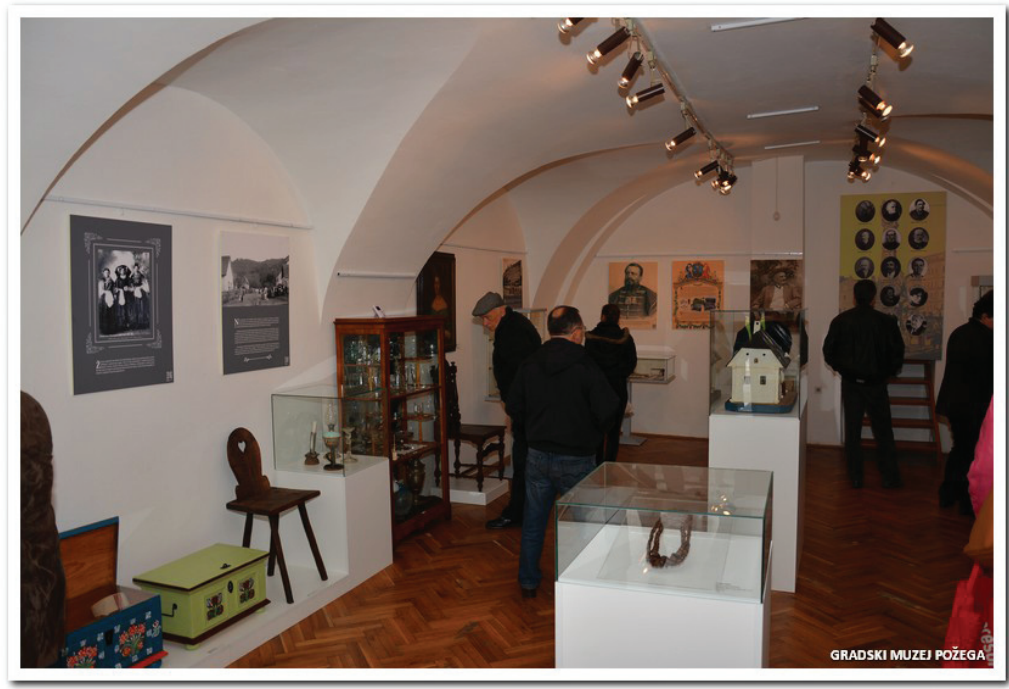

Slika 4. Privremeni postav iz 2014.g., GMP

grame, novi privremeni stalni postav bio je smješten samo na oko $60 \mathrm{~m}^{2}$. Predmeti su bili izloženi prema cjelinama. Zasebno se prezentirala građa Arheološkog i Povijesnog odjela kroz kronološku priču o povijesti Požeštine i Požege, dok su predmeti iz Etnološkog odjela i Odjela povijesti umjetnosti prezentirani kao jedna cjelina prikazujući grad Požegu i okolna sela kroz svakodnevni život i uređenje kuće.

10 Uporabni, ali i ukrasni kućni predmeti svjedočili su o društvenom statusu obitelji s prijelaza iz 19. u 20. stoljeće u gradu, ali i u bogatim seoskim kućama. Isto tako bogatstvo i društveni ugled obitelji održavao se i u ženskom odijevanju i ukrašavanju.

11 Za vodstvo grupa koje su više puta posjećivale privremeni postav, a da bi se izbjeglo ponavljanje iste priče o prošlosti požeškoga kraja, izabirani su pojedini predmeti ili grupa predmeta sa zanimljivom tematskom cjelinom. 


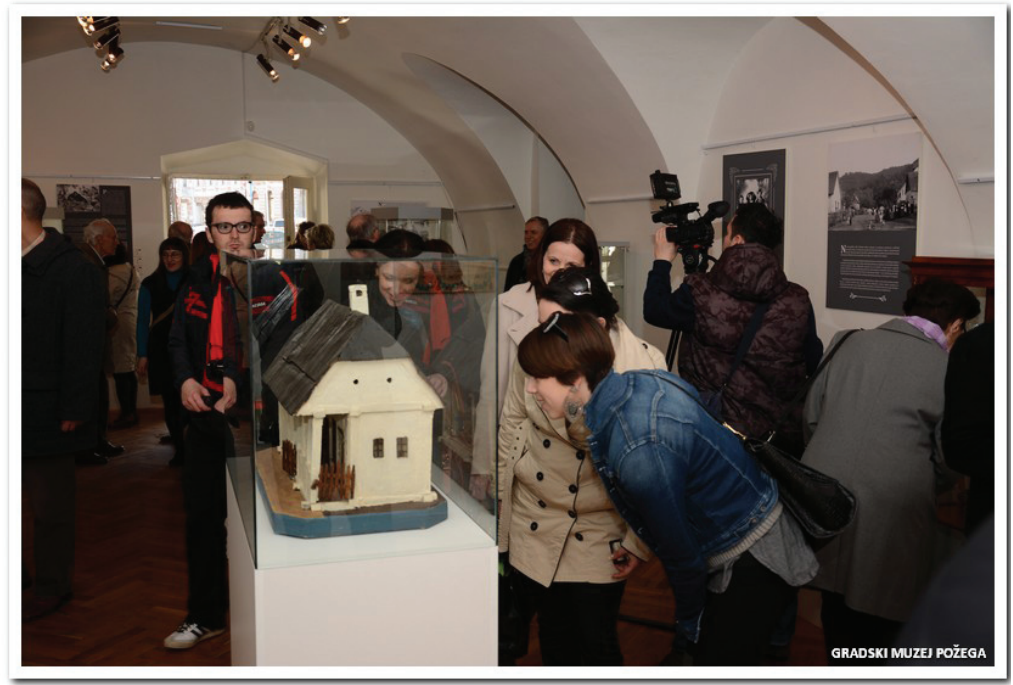

Slika 5. Maketa zadružne kuće u postavu 2014.g., GMP

Višegodišnja komunikacija s posjetiteljima kroz Posljednji privremeni postav? pokazala je višeznačnost interpretacije samog predmeta. Privlačan zbog svog slikovitog izgleda, bio je vrlo pogodan za edukativna vodstva najmlađe generacije - djece. Upravo su ta iskustva naglasila važnost tog muzejskog predmeta kao izvora znanja koje nam daje veliku količinu podataka. Osim što nam prezentira način stanovanja i življenja u tradicijskoj zadružnoj kući druge polovice 19. stoljeća, donosi nam i priču o životu požeškoga seljaka onoga vremena, „od svagdana do blagdana“, kao i o samom etnografu i pučkom stvaraocu Ivi Čakaliću. Iz toga je proizašla zamisao da maketa kuće bude inspiracija za tematsku ideju vodilju budućeg etnografskog dijela postava muzeja. Nastojalo se dakle značajke tradicijske kulture sela Požeštine s kraja 19. i prve polovice 20. stoljeća prikazati u sklopu tradicijske zadružne kuće kao prvog prostornog okvira seljačkoga života.

\section{Tematska cjelina Družinska kuća Ive Čakalića - rekonstrukcija organi- zacije života sela Požeštine od blagdana do svagdana}

U obnovu muzeja nakon potresa 1995. godine koji je aktualizirao potrebnu temeljitu adaptaciju muzejskog kompleksa uključuju se i Muzejski dokumentacijski centar i Institut za povijest umjetnosti izrađujući Idejni prijedlog Gradskog muzeja u Požegi (Žebčević Matić, 2011). Nekoliko godina nakon toga, 2005. godine, kustosice $^{12}$ požeškog muzeja izradile su muzeološku koncepciju budućeg stalnog postava

12 Autorice koncepcije bile su Dubravka Sokač Štimac, Mirjana Šperanda, Lidija Španiček, Dubravka Matoković i Maja Žebčević Matić. 
na $1.600 \mathrm{~m}^{2}$ koju je prihvatilo Hrvatsko muzejsko vijeće (Šperanda, 2009). Stalni postav zamišljen je tako da na kronološki način prezentira prošlost Požege i požeškoga kraja kroz kružni tok u tri zgrade od podruma do prvog kata u tri cjeline: kulturnu historiju, galeriju i etnografiju. Etnografski dio postava trebao je kao zasebna cjelina prezentirati društvenu, duhovnu i materijalnu kulturu požeškoga ruralnog kraja na prostoru od $99,25 \mathrm{~m}^{2}$. Predmeti iz raznih zbirki trebali su prikazati ambijentalnim i multimedijalnim putem tekstilno, lončarsko i drvodjeljsko rukotvorstvo te pojedine godišnje i životne običaje Požeštine. U istom dijelu trebala se predstaviti i ostavština Ive Čakalića (Muzeološka koncepcija Stalnog postava Gradskog muzeja Požega, 2005). Iste godine na osnovi te koncepcije izrađeno je Idejno rješenje adaptacije muzejskih zgrada. Međutim, zbog neriješenih imovinskopravnih odnosa, adaptaciju muzeja nije bilo moguće ostvariti godinama (Šperanda, 2009; Žebčević Matić, 2011). $\mathrm{U}$ čekanju rješenja toga problema u desetak godina uvidjeli su se, osim prednosti, i nedostaci novog postava, a muzej je u međuvremenu razvijao nove projekte (Muzej u loncu) te je uspostavio pedagošku djelatnost i jaču interakciju za zajednicom. Zbog toga se javljaju potrebe za novim prostorima kojih je u prvotnoj idejnoj koncepciji iz 2005. godine nedostajalo, poput prostora za radionice, čuvaonice i druge potrebne muzejske sadržaje. Pristupilo se smanjivanju stalnog postava na jednu etažu kata zadržavajući pritom odobrenu muzeološku koncepciju. ${ }^{13}$ Nakon toga pristupilo se izradi scenarija budućeg stalnog postava.

Budući izložbeni prostor stalnog postava projektiran je kao jedinstven prostor koji bi se rasporedom eksponata i elementima interijera organizirao u više tematskih izložbenih cjelina. ${ }^{14}$ Jedna od njih jest i tematska cjelina Družinska kuća Ive Čakalića - rekonstrukcija organizacije života sela Požeštine od blagdana do svagdana koja će biti prezentirana, za razliku od prvobitne koncepcije, u nešto smanjenom prostoru od 69 $\mathrm{m}^{2}$. U osmišljanju scenarija za postav pošlo se od novonastalih okolnosti i prilagodilo se specifičnosti zadanog prostora. U njemu je iskazana zamisao da se tradicijski seoski život prikaže u sklopu arhitektonske naznake tipične zadružne kuće, kroz koju se zrcali gospodarska djelatnost, oblik i organizacija obitelji te njezin društveni i duhovni život. Duguljasta drvena kuća s usječenim trijemom i trima prostorijama s kraja 18. stoljeća karakteristična je za starosjedioce požeškoga kraja, kasnije se javlja trijem uzduž cijele kuće ili verzija skraćenog trijema (Lechner, 1979), kakav ima Čakalićeva maketa. Njezin raspored prostorija od glavne, družinske sobe, namijenjene boravku cijele obitelji, zatim kuhinje zvane kućom, s ognjištem, te sobe za gazdu, ostat će najkarakterističniji tip kuće do polovice 20. stoljeća (Matoković, 2004). Na kuću

13 Tu koncepciju prilagođenu novonastalom stanju potvrdilo je Hrvatsko muzejsko vijeće 2016. godine.

14 Prirodne značajke požeškog kraja, Prapovijest i antika, Od srednjeg vijeka do slobodnog kraljevskog grada, Vlastela požeškog kraja, Građanske obitelji Požege, Društveni život, Glazbeni život, Julije Kempf, osnivač muzeja, Požeška ulica, Trgovina umjetničkog obrta, 20. stoljeće, Družinska kuća Ive Čakalića i Galerija slika. 
su se mogli nadograđivati kijeri, male prostorije za bračne parove. Etnološka cjelina prezentirat će se u linearnim odjeljcima po uzoru na organizaciju zadružne kuće u četiri manje cjeline: družinsku sobu, kuću, sobu Ive Čakalića i kijer (slika 6).

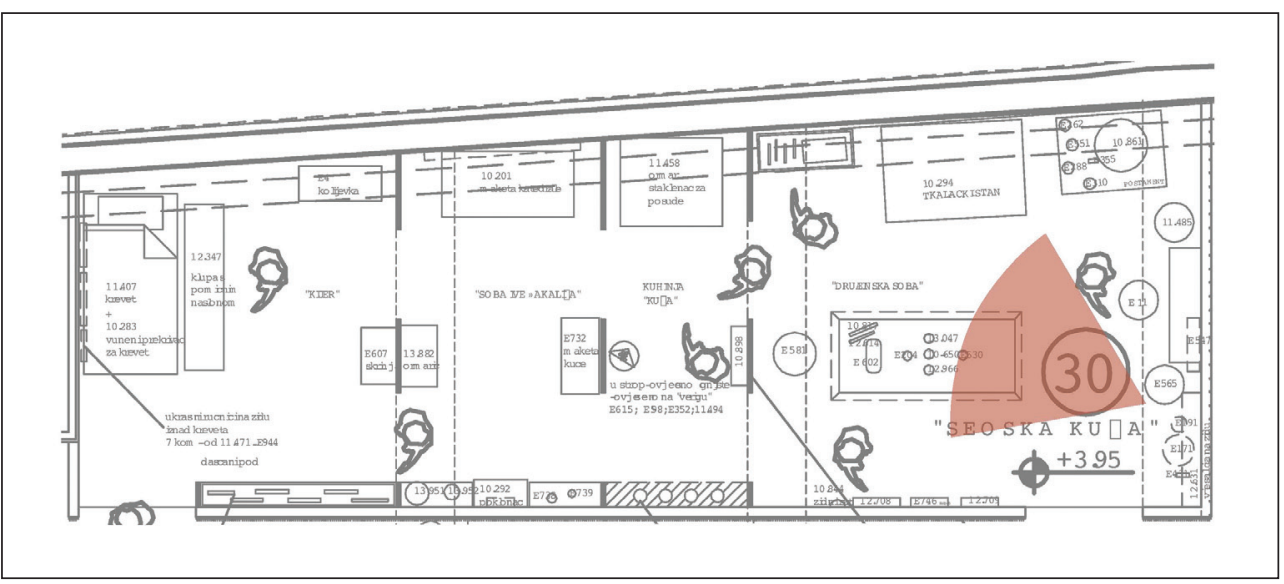

Slika 6. Tlocrt tematske cjeline „Družinska kuća Ive Čakalića - rekonstrukcija organizacije života sela Požeštine od blagdana do svagdana"

U družinskoj sobi scenografskom rekonstrukcijom sobe uz multimedijski prikaz predstavio bi se prikaz svakodnevnog i blagdanskog života. Soba je zauzimala središnje mjesto u seoskoj zadružnoj kući. U njoj se boravilo, radilo, objedovalo, spavalo, slavilo, rađalo i umiralo, odnosno u njoj se odvijao cjelokupni svakodnevni život jedne obitelji (Španiček, 1995). Soba je bila središte životnih i većine godišnjih običaja. Ona najbolje prikazuje zajednicu života i rada zadružne obitelji. Scenografskom rekonstrukcijom odabranog namještaja sobe i alatom za tradicionalno rukotvorstvo prezentirale bi se navedene značajke družinske sobe.

Prostorija u kojoj se pripremala hrana nazivala se kuća, a bila je smještena između družinske sobe i gazdinske sobe. U ovom odjeljku scenografski bi se prezentirala kuhinja s inventarom kakav je bio u većini seoskih domova do početka 20 stoljeća. U kući se kuhalo na otvorenoj vatri niskog ognjišta smještenog u sredini same prostorije. Oko ognjišta bili su poredani zemljani lonci. Izloženo kuhinjsko posuđe koje su izrađivali seljaci, lončari iz Golog Brda, i pokljuke, peke majstora iz Novog Sela, dokumentirali bi segment života 19. stoljeća, kada se hrana kuhala u loncima i pekla ispod peke na otvorenom ognjištu (Matoković, 2009). Prezentacijom posuđa od prirodnih materijala dao bi se uvid u taj segment tradicijskog rukotvorstva i obrta. 
Treća prostorija, stražnja soba - sobica, smještena do kuhinje i funkcionalno pomalo izdvojena, u 18. i 19. stoljeću bila je namijenjena kućnom starješini ili za primanje gosta (Španiček, 1995). Bolje uređena imala je reprezentativan karakter primanja uglednijih gostiju. U ovom odjeljku predstavila bi se djelomično rekonstruirana soba Ive Čakalića, seljaka etnografa i pučkog umjetnika, s njegovim maketama i skulpturama kao mali kućni muzej njegovih radova. Kao nadopunu njegovim djelima izložili bi se i dekorirani drveni predmeti svakodnevne uporabe kao primjeri tradicijskog rukotvorstva u drvu.

Nekada su se u sklopu dvorišta ili na kuću dograđivali kijeri - male prostorije za bračne parove koje su služile za spavanje. Svaki bračni par imao je svoj kijer, gdje je spremao svoju privatnu imovinu. U djelomičnoj scenografskoj rekonstrukciji te sobe prikazao bi se oskudni inventor mladog bračnog para s prijelaza iz 19. u 20. stoljeće. On se sastojao od kreveta, škrinje za spremanje odjeće, tekstilnog posoblja iz mladenkina ruha i eventualno kolijevke. U odjeljku kijera predstavila bi se prva noć mladog vjenčanog para, običaja slaganja, kada mladenci u pratnji glavnih svatovskih časnika odlaze u kijer, gdje mladoženja skida mladenki vijenac kao znak prestanka djevojaštva. Krevet mladenaca prekriven je vunenim prekrivačem - šarenicom - s tradicijskim motivima koji simboliziraju plodnost za osiguranje potomstva novoga bračnog para.

Zamisao je da se opisane scenografske rekonstrukcije u kombinaciji s izloženim predmetima poprate multimedijski uz prikladne legende, fotografije, dokumentarni film, akustiku i izrađenu maketu družinske kuće kao didaktičko-taktilnim pomagalom. Maketom bi se stvorila mogućnost opipavanja njezinih kontura i umanjenog namještaja za slabovidne te igre i samostalno uređivanje prostorija kuće za djecu, ali i za odrasle. Pomno osmišljena multimedija s kreiranom igrom sastavljanja kuće i dodatnom bazom podataka za posjetitelje upotpunila bi stalni postav i dala širinu njegovu etnografskom dijelu.

\section{Zaključak}

Maketa tradicijske višeprostorne kuće iz Zbirke Ive Čakalića bila je sastavni dio nekoliko stalnih postava Gradskog muzeja Požega. Autor Ivo Čakalić, pučki umjetnik i seljak iz Doljanovaca, izradio ju je po uzoru na svoju rodnu kuću iz sredine 19. stoljeća. Primjer je tipičnog oblika tradicijske slavonske kuće. Opisani muzejski predmet na edukativan i svim uzrastima pristupačan način dokumentira izgled, funkciju i način stanovanja požeških seljaka od sredine 19. do početka 20. stoljeća. Na osnovi toga sam predmet postao je tematska ideja vodilja buduće tematske cjeline stalnog postava Gradskog muzeja Požega pod nazivom Družinska kuća Ive Čakalića - rekonstrukcija organizacije života sela Požeštine od blagdana do svagdana. Ideja je da se značajke tradicijske kulture sela Požeštine s kraja 19. i prve polovice 20. stoljeća prikažu u sklopu tradicijske kuće koja je bila prvi prostorni okvir seljačkoga života. 


\section{Literatura}

Lechner, Zdenka (1979), Etnografske značajke požeškoga kraja. Vjesnik Muzeja Požeške kotline, 2 -3, str. 235-247.

Matoković, Dubravka (2004), Etnografske značajke požeškoga kraja. U: N. Čerti (ur.), Kulturna baština Požege i Požeštine. Požega: Spin Vallis, str. 208-302.

Matoković, Dubravka (2009), „Kuharice budi čista, nek Ti suđe uvjek blista“, etnografska izložba posuđa i pribora za jelo i piće. Požega: Gradski muzej Požega.

Matoković, Dubravka (2014), Drvo u tradicijskoj kulturi, Tradicionalno i suvremeno oblikovanje drveta, brošura muzejske radionice i etno prezentacije, Požega: Gradski muzej Požega.

Španiček, Žarko (1995), Narodno graditeljstvo Slavonije i Baranje, Privlačica, Vinkovci. Španiček, Žarko (2009), Tradicijsko graditeljstvo. U: B. Biškupić (gl. ur.) Slavonija Baranja i Srijem, vrela europske civilizacije, Zagreb: Galerija Klovićevi dvori, str. 35-52.

Šperanda, Mirjana (2009), Kronologija - 85. obljetnica Gradskog muzeja Požega. Vjesnik gradskog muzeja Požega, 6, str. 4-12.

Žebčević Matić, Maja (2011), 80 godina od prvog postava požeškoga muzeja - Pri$\log$ za proučavanje povijesti Gradskog muzeja Požega. Glasnik slavonskih muzeja, XXIX 6 (61), str. 10-16.

\section{Izvori}

Zbirka Ive Čakalića, Računalni inventarni program M++, Gradski muzej Požega Dokumentacijska zbirka, Fototeka

Muzeološka koncepcija Stalnog postava Gradskog muzeja u Požegi, 2005.

Stručna arhiva Etnološkog odjela (Privremeni postav Etnografskog dijela 2006.g., Posljednji privremeni postav?, 2014.)

Suglasnost za preinaku muzeološke koncepcije Gradskog muzeja Požega, ur. broj: 231/15, 2015.

Scenarij: Tematska cjelina "Družinska kuća Ive Čakalića - rekonstrukcija organizacije života sela Požeštine od blagdana do svagdana", Etnografski postav, Prostorija 30, 2016./2017. 


\section{A Museum Interpretation of the Way of Life in the Požega Valley - the Example of Ivo Čakalić's Scale Model of a Traditional House}

\section{Summary}

The scale model of a traditional multipurpose folk house from Ivo Čakalić's Collection formed a part of several permanent displays at the Požega City Museum. The author Ivo Čakalić, folk artist and peasant from Doljanovci, made this model based on his own family home built in the mid-19th century. This exhibit represents a typical form of a traditional Slavonian house. In an educative and accessible fashion for all ages, it documents the way a peasant house from the Požega area looked like and functioned in the period between the mid-19th and the beginning of the 20th century. It further represents a record of the peasant lifestyle there and then. Multiple possibilities of interpreting this exhibit have been demonstrated in the yearlong communication with visitors. The item itself has become a guiding idea in representing the ethnographic part of the future museum display. The idea is to show the typical features of the traditional culture in the Požega area in the late 19th and the first half of the 20th century, and present them in the form of a traditional house the first spatial framework of peasant life.

Keywords: traditional house; exhibit; traditional culture; Ivo Čakalić; permanent display.

Dubravka Matoković, prof., muzejska savjetnica

Gradski muzej Požega

Matice hrvatske 1, 34000 Požega

dubravkam@gmp.hr 